distemonanthin. Unfortunately, there is no quick method for distinguishing between the two types of wood, nor is it known how the two types are distributed in commercial supplies, but a variation in extractive content such as this may account for the sporadic occurrence of ayan dermatitis.

The above results do not exclude that there may be other unidentified sensitizing constituents in the crude methanol extract which are not so readily isolated.

The authors wish to acknowledge the help of Dr. F. E. King, of B.P. Limited, in making available samples of pure extractive for test, and that of Mr. D. Patterson, of the Timber Research and Development Association,
Glasgow, in providing a liaison service which made this work possible. This paper is published by permission of the Ministry of Technology.

\section{REFERENCES}

Bourne, L. B. (1956). Brit. F. industr. Med., 13, 55.

Calnan, C. D. (1963). In Clinical Aspects of Immunology, ed. Gell and Coombs, p. 516. Blackwell Scientific Publications, Oxford.

King, F. E., King, T. J., and Sellars, K. (1952). f. chem. Soc., p. 92.

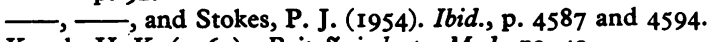

Krogh, H. K. (1962). Brit. F. industr. Med., 19, 42. (1964). Ibid., 21, 65 .

Sandermann, W., and Barghoorn, A. W. (1955). Holzforschung, 9, 112.

Schulz, K. H. (1962). Berufsdermatosen, 10, 17.

\title{
Pulmonary Hypersensitivity to the Grain Weevil
}

\author{
J. A. LUNN and D. T. D. HUGHES \\ From Slough Industrial Health Service and the Pulmonary Function Laboratory, London Hospital
}

A case of inhalant allergy to the grain weevil is described. Provocation inhalations of the weevil protein produced immediate responses shown by falls of as much as $25 \%$ in the F.E.V.1.0. These changes were reversed by a bronchodilator. Arthus-type reactions also occurred approximately three hours after the inhalation of protein. In these the transfer factor was reduced by $25 \%$ and was not affected by a bronchodilator. Antihistamines were found to inhibit the immediate response but to have no effect on the Arthus reaction.

Coincident with the fall in transfer factor there were rises in the temperature and pulse rate. An Arthustype as well as an immediate skin response was demonstrated. Precipitating antibodies were detected in the serum.

The similarity of these reactions to those seen in farmer's lung and to reactions to avian protein is discussed, together with the possibility of the wider implications of sensitivity to the grain weevil.

Pulmonary reactions to inhaled allergens are well recognized and seem to fall into two groups. The first is associated with an immediate reaction with wheezing and a change in the forced expiratory volume; and a second variety is associated with a more delayed response or Arthus-type hypersensitivity with systemic upset and a change in the transfer factor. The report of hypersensitivity to pigeon and budgerigar excreta (Hargreave, Pepys, Longbottom, and Wraith, 1966) has recently drawn attention to this latter type of reaction. This report showed that pigeon and budgerigar fanciers suffered from pulmonary disease associated with impaired

Received for publication July 4, 1966. lung function. In particular there were changes in lung function associated with systemic upsets occurring some hours after the inhalation of the allergen and with a pattern rather similar to that of farmer's lung.

Asthma caused by the grain weevil (Sitophilus granarius) has been described (Frankland and Lunn, 1965; Lunn, 1966). Further pulmonary function studies, skin reactions, and antibody tests have been made on one of the subjects described. In particular the immediate and later effects of the inhalation of weevil extract and the effect of antihistamines in preventing reactions has been studied, together with changes in temperature, pulse, and skin reaction. 
Materials and Methods

Pulmonary Function Studies Routine simple tests were carried out using the standard methods employed in the Pulmonary Function Laboratory of the London Hospital (Hughes and Lee, 1963) and I\% extracts of weevil were used in inhalation provocation tests. The solvent and weevil extract were inhaled through a mask after nebulization in a Wright's nebulizer through which oxygen was passed at a flow rate of 4 litres per minute.

Skin Testing Intradermal skin testing was performed using $1 \%$ weevil extract, and the reactions were observed over a period of several hours.

The Subject R.K. was a healthy girl of 19 years who had had no history of chest trouble or allergic responses until she began working in a laboratory where she was exposed frequently to the grain weevil. After six months she developed sneezing, conjuctivitis, and urticaria when exposed to the dust from the insect. Within a further month she developed asthma. Skin testing to the grain weevil was positive with a positive PrausnitzKustner transfer test. Since removal from contact with the grain weevil she has been free from any asthmatic or allergic manifestations for 18 months. Clinical examination revealed no abnormality and her blood count, E.S.R., and chest radiograph were normal.

\section{Results}

Simple tests of pulmonary function were all normal as shown in Table I. She gave remarkably consistent results; for example, her F.E.V.1.0 measured over a five-hour period during the day varied only between 2,900 and $3,025 \mathrm{ml}$, , or $3 \%$, in I6 measurements. Similarly, her transfer factor varied only between 20 and $21 \mathrm{ml} . / \mathrm{mm} . \mathrm{Hg} / \mathrm{min}$. in the course of four duplicate estimations by the single-breath method carried out over a two-and-ahalf-hour period.

Provocation Tests In the first study she was given an inhalation of solvent as a control and there was no change in her F.E.V.1.0. She then received an eight-minute inhalation of $1 \%$ weevil extract. This produced a fall in F.E.V $\cdot_{\mathbf{1 . 0}}$ which was maximal in 30 minutes, by which time it had fallen from 2,800 to $2,100 \mathrm{ml}$., a change of $25 \%$. This was associated with a feeling of tightness in the throat and chest. There was an $18.5 \%$ change in vital capacity from $3,300 \mathrm{ml}$. to $2,800 \mathrm{ml}$. A bronchodilator aerosol reversed this change, the vital capacity reverting to $3,250 \mathrm{ml}$., and the F.E.V.1.0 $2,725 \mathrm{ml}$., within $3.0 \%$ of the original value. The subject then returned home, but that evening, four hours later, she developed cough, breathlessness,
TABLE

Lung Function Tests

\begin{tabular}{|c|c|c|}
\hline Lung Volumes (ml.) & Observed & $\begin{array}{c}\text { Percentage } \\
\text { of Predicted } \\
\text { Value }\end{array}$ \\
\hline $\begin{array}{l}\text { Vital capacity } \\
\text { Inspiratory capacity } \\
\text { Expiratory reserve volume } \\
\text { Functional residual capacity } \\
\text { Residual volume (R.V.) } \\
\text { Total lung capacity (T.L.C.) } \\
\text { R.V./T.L.C. }\end{array}$ & $\begin{array}{l}3,300 \\
2,200 \\
1,100 \\
2,150 \\
1,050 \\
4,350 \\
24 \%\end{array}$ & $\begin{array}{r}100 \\
100 \\
100 \\
96 \\
92 \\
98\end{array}$ \\
\hline \multicolumn{3}{|l|}{ Ventilation } \\
\hline $\begin{array}{l}\text { Vital capacity }(\mathrm{ml} .)^{1} \\
\text { F.E.V. } \cdot 1 \cdot 0(\mathrm{ml} .)^{1} \\
\text { F.E.V.\% } \\
\text { P.E.F. }(1 . / \mathrm{min} .)^{1} \\
\text { Maximum voluntary } \\
\quad \text { ventilation }(1 . / \mathrm{min} .)^{1} \\
\text { Respiratory rate/min. } \\
\text { Tidal volume }(\mathrm{ml} .) \\
\text { Minute volume }(1 . / \mathrm{min} .)\end{array}$ & $\begin{array}{r}3,300 \\
2,800 \\
85 \\
400 \\
\\
90 \\
15 \\
500 \\
7 \cdot 5\end{array}$ & \\
\hline $\begin{array}{l}\text { Transfer factor (single-breath } \\
D_{\text {LCo }} \text { ) }\end{array}$ & \multicolumn{2}{|c|}{$\begin{array}{l}22 \mathrm{ml} . / \mathrm{mm} . \mathrm{Hg} / \mathrm{min} . \\
(100 \% \text { predicted })\end{array}$} \\
\hline
\end{tabular}

${ }^{1}$ A bronchodilator aerosol did not alter these values.

2Predicted values taken from Goldman and Becklake (1959), Amer. rev. Tuberc., 79, 457.

and a tight feeling in the chest which persisted until the next morning.

Because of this delayed reaction she was challenged again two weeks later with the extract by inhalation and changes followed in F.E.V.1.0, temperature, pulse rate, and skin reaction over a period of several hours. Figure I shows that following a five-minute inhalation of weevil extract there was an immediate and a late fall in F.E.V.1.0. The initial change, which was maximal after 50 minutes, was $12.5 \%$. The F.E.V.1.0 then increased, though not regaining its original value, but after three hours fell to $2,250 \mathrm{ml}$., a drop of $20 \%$ from the initial value. Thereafter it remained reduced for some hours further so that 400 minutes after the initial inhalation it was still only $2,300 \mathrm{ml}$. At this stage a bronchodilator aerosol did not restore the F.E.V.1.0. The pulse rate remained reasonably constant for the first two and a half hours but showed a marked change at 150 and 170 minutes, rising from 72 to 90 beats per minute. The rise in pulse rate coincided with a steep secondary fall in F.E.V.1.0. The temperature seemed to show a biphasic response, there being a rise of $\mathrm{I} \cdot 4^{\circ} \mathrm{F} .\left(0 \cdot 8^{\circ} \mathrm{C}\right.$.) occurring maximally at 40 minutes and a similar 


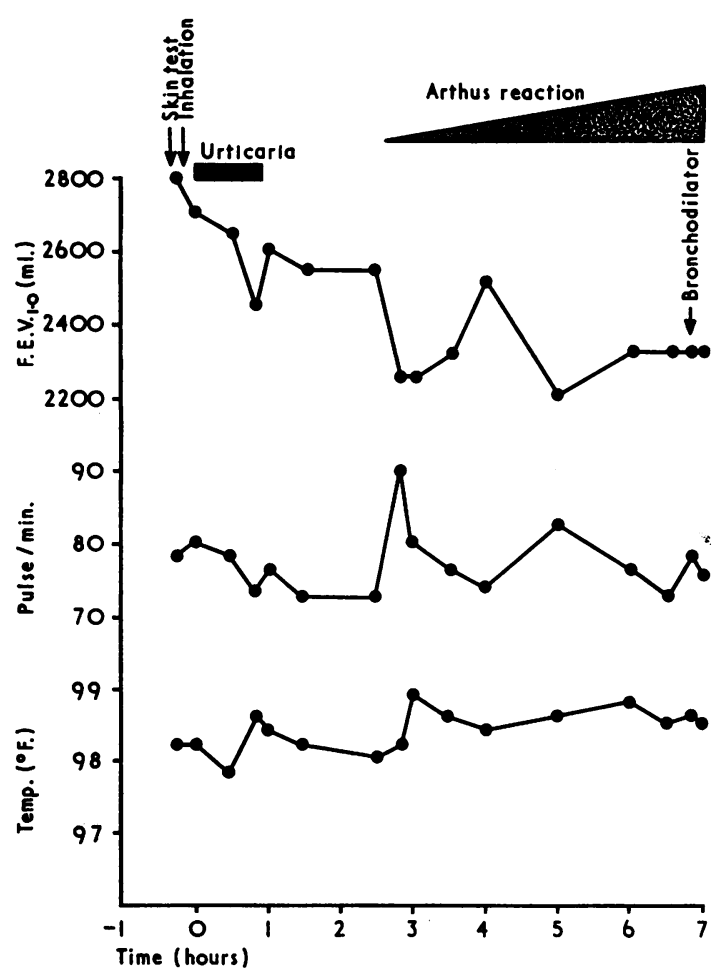

FIG. I. The effect of a provocation inhalation on F.E.V.1.0, and the skin responses to an intradermal test.

secondary rise coinciding with the change in pulse rate and F.E.V.1.0. An intradermal test was performed immediately before inhalation. This produced an immediate urticarial weal and flare reaction with considerable itching. This was maximal at 15 minutes with a weal of $12 \mathrm{~mm}$. diameter and a flare of $50 \mathrm{~mm}$. diameter. It generally faded and at 40 minutes had disappeared. In just under three hours (160 minutes) a characteristic Arthus-type reaction developed, measuring $30 \times 40 \mathrm{~mm}$. This area of diffusely raised erythema steadily increased in size and persisted until the next morning when it was $150 \times 80 \mathrm{~mm}$. Although it began to fade it was still present 48 hours later.

In view of this Arthus-type reaction, it was decided to repeat the test, making measurements of the transfer factor by the single-breath carbon monoxide method. The results are shown in Figure 2. Again there were similar changes in F.E.V.1.0, temperature, and pulse, though they were less marked than in the previous study, possibly because there was no skin testing and reaction. The interesting finding was a later fall in the transfer factor which was only $75 \%$ of its original value four hours after provocation. In absolute values it fell from 20 to $15 \mathrm{ml} . / \mathrm{mm}$. $\mathrm{Hg} / \mathrm{min}$. In addition scattered crepitations were heard at the lung bases three and four hours after the inhalation. Changes were followed for up to five hours and at the end of the experiment a bronchodilator aerosol was without effect on the F.E.V.1.0 or transfer factor.

Finally the effect of an antihistamine was tested. Chlorpropheniramine, $4 \mathrm{mg}$., was taken by mouth two hours before and two hours after the provoking inhalation. The drug modified the initial but not the delayed response, as shown in Figure 3. There was virtually no change in F.E.V.1.0 in the first hour (a $3.4 \%$ change, barely outside the limits of variation under control circumstances). There was a further fall of $100 \mathrm{ml} .(3 \cdot 4 \%)$ at three hours. There was a delayed fall in the transfer factor, as had occurred without the antihistamine. The maximal change was from a control value of 19.5 to one of $14.5 \mathrm{ml} . / \mathrm{mm}$. $\mathrm{Hg} / \mathrm{min}$., a change of $25.7 \%$, almost identical to that obtained previously. The secondary rise in pulse was unaffected and again occurred at three hours. The later temperature rise still occurred but may have been modified slightly in that on this occasion it did not occur until after four hours. Because of the previous severe skin reaction an intradermal prick test was performed. There was no immediate urticarial reaction, but an area of

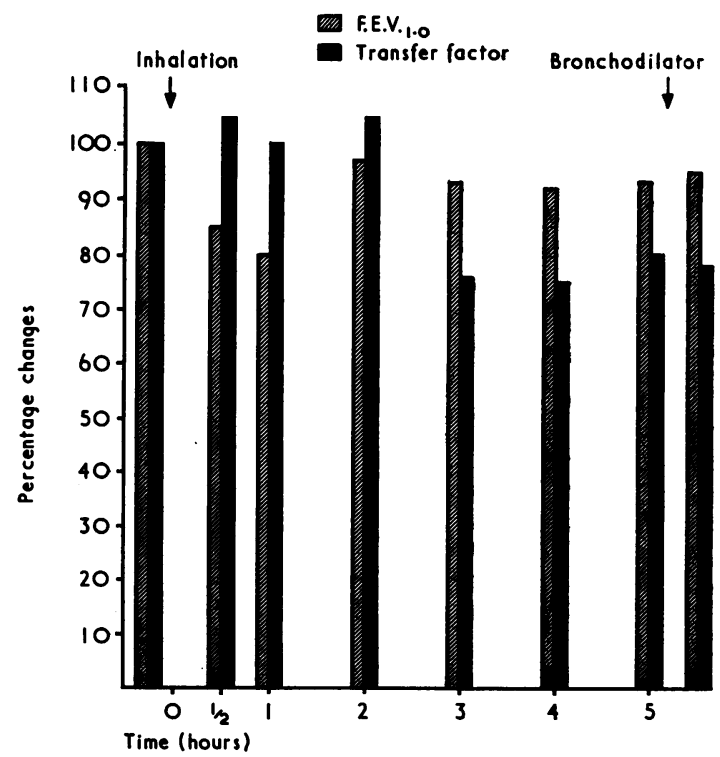

FIG. 2. Histogram of percentage change in F.E.V.1.0 and percentage change in transfer factor and the effect of a bronchodilator aerosol. 


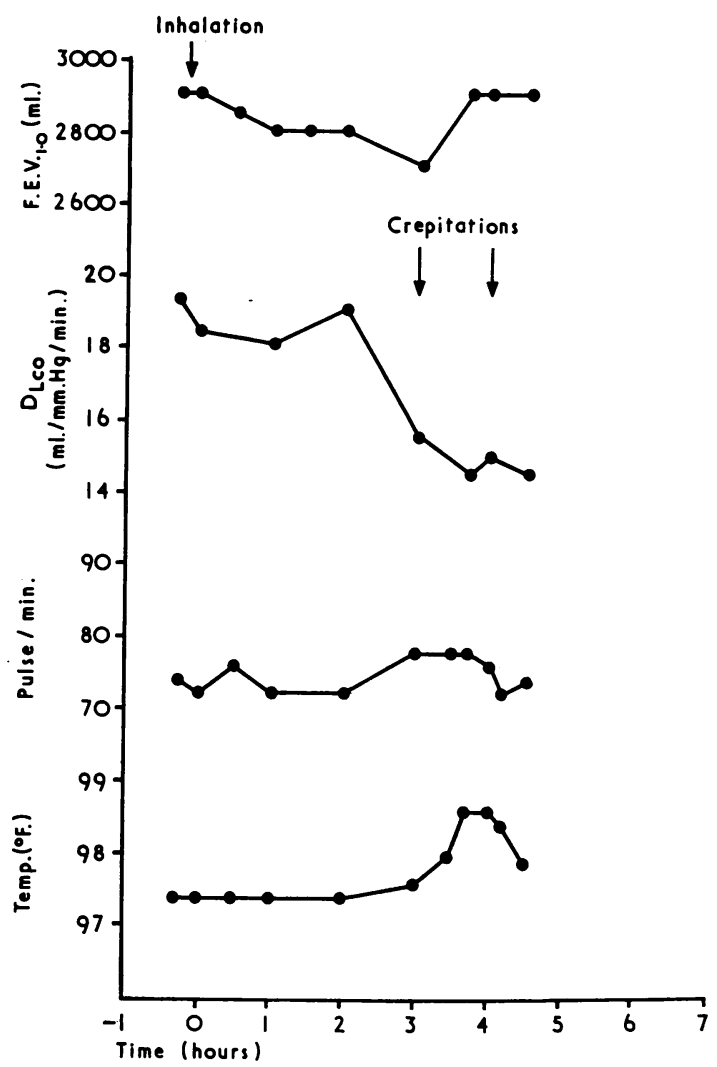

FIG. 3. The effect of chlorpropheniramine on the response to inhalation.

itchy erythema appeared 20 minutes later, measuring $25 \mathrm{~mm}$. in diameter at half an hour and slightly increased in size at one hour. Thereafter it faded slowly but did not completely disappear until two and a half hours after the initial test. There was no further skin reaction.

Control Studies Twenty-five healthy subjects were given five-minute inhalations of weevil protein without any changes occurring in their lung function.

Serological Tests Precipitin reactions between the patient's serum and weevil extract were demonstrated by the double diffusion method in an agargel plate following a two and a half times concentration of the serum.

\section{Discussion}

Our results in this subject show certain interesting features. First there was an immediate asthmatic type response to the inhaled allergen followed some hours later by an Arthus-type response. Further, these reactions are affecting different parts of the lung structure. The former, due to a change in the airways, occurs rapidly and can be reversed by a bronchodilator aerosol and prevented by an antihistamine. The more delayed type of reaction, involving the gas exchanging part of the lungs and associated with systemic symptoms, crepitations, temperature and pulse changes, and decreased transfer factor, was unaffected by an antihistamine and by isoprenaline inhalation. Besides a biphasic response in the lungs there was a similar double response in the skin, namely an immediate urticarial reaction followed some hours later by an Arthustype reaction. Further, precipitating antibodies were found in the serum. The delayed reaction with changes in transfer factor, Arthus skin reaction, and precipitating antibodies is very similar to those found in farmer's lung and to the recently described disease found in pigeon and budgerigar fanciers (Hargreave et al., 1966). In both these conditions with repeated exposure to the provoking substances a permanent structural change can occur in the lung leading to an interstitial fibrosis with permanent alteration in lung function. When removed from exposure to the grain weevil this patient lost her symptoms. Pulmonary and systemic reactions could be produced, however, by inhalation and were associated with transient lung function changes although her chest radiograph and lung function before provocation were still completely normal. She therefore represents an early stage in the illness and fortunately has been removed from exposure before permanent damage to the lung has occurred.

We should like to thank Dr. J. Pepys and Dr. T. A. L. Rees, Medical Research Council Immunology Research Group, Institute of Diseases of the Chest, Brompton Hospital, for the serological investigations and Mrs. Margaret Burnard for technical assistance with the pulmonary function studies.

\section{REFERENCES}

Frankland, A. W., and Lunn, J. A. (1965). Brit. F. industr. Med., 22, 157 .

Hargreave, F. E., Pepys, J., Longbottom, J. L., and Wraith, D. G. (1966). Lancet, I, 445 .

Hughes, D. T. D., and Lee, F. I. (1963). Thorax, 18, 16. Lunn, J. A. (1966). Brit. F. industr. Med., 23, 149. 